\title{
Pelatihan dan Pendampingan Penyusunan Kebijakan dan Standar Pelayanan Publik pada Balai Teknik Air Minum
}

\author{
Eko Aristanto', Indri Damayanti², Zaenal Aripin ${ }^{3}$ \\ 'Departemen Keuangan dan Perbankan, Fakultas Ekonomi dan Bisnis \\ Universitas Merdeka Malang, Jl. Terusan Raya Dieng No. 62-64, Malang, 65146, Indonesia \\ Biro Komunikasi Publik, Sekretariat Jenderal \\ Kementerian Pekerjaan Umum dan Perumahan Rakyat, Jl. Patimura, DKI Jakarta, 12110, Indonesia \\ ${ }^{3}$ Departemen Manajemen, Fakultas Ekonomi \\ Universitas Sangga Buana YPKP, Jl. PH.H Mustofa (Suci), Bandung, 40124, Indonesia
}

\begin{abstract}
ARTICLE INFO
Received: 2021-02-15

Revised: 2021-03-08

Accepted: 2021-04-03

Keywords:

Public service standards, Technical assistance, Training

\section{ABSTRACT}

The implementation of this activity aims to improve the management of policy documents and service standards, increase the capacity of implementing resources and increase the value of public service performance at Balai Teknik Air Minum. Methods of implementing activities include socialization and field visits, desk documents, training and assistance related to public service policies and standards. The duration of the activity is 13 (thirteen) effective working days. Achievements in the implementation of these training and mentoring activities include: i) identified various weaknesses in improving the performance of public services that have been implemented, ii) increasing understanding of leaders and implementers of public services about managing policy documents and public service standards, iii) preparation of policy documents and public service standards which refers to the PANRB Ministerial Regulation No. 15/2014 and the PANRB Minister Regulation No. 17/2017, iv) The results of the selfassessment show an increase in the performance of public services from 2.66 (53.30) category $C$ (Enough) to 3.45 (69.13) category B- (Good with Notes). The results of the evaluation of training and assistance activities in the preparation of policy governance documents and public service standards on 5 (five) indicators reached a score of 54 in the very good category.
\end{abstract}

(C)2021 Published by University of Merdeka Malang. This is an open access article distributed under the CC BY-SA 4.0 license (https://creativecommons.org/licenses/by-sa/4.0/)

How to cite: Aristanto, E., Damayanti, I., \& Aripin, Z. (2021). Pelatihan dan Pendampingan Penyusunan Kebijakan dan Standar Pelayanan Publik pada Balai Teknik Air Minum. Abdimas: Jurnal Pengabdian Masyarakat Universitas Merdeka Malang, 6(2), 153-165. https://doi.org/10.26905/abdimas.v6i2.5465

\section{PENDAHULUAN}

Pelayanan publik merupakan pondasi dasar penyelenggaraan pemerintahan dan sekaligus indikator penilaian kinerja pemerintah (Aini, 2019). Mengingat pentingnya pelayanan publik bagi masyarakat, tentunya mendorong berbagai organisasi publik untuk bekerja efektif, inovatif dan efisien 
ABDIMAS: Jurnal Pengabdian Masyarakat Universitas Merdeka Malang

Volume 6, No. 2, May 2021: 153-165

(Tunggul et al., 2016). Pelayanan publik adalah bentuk kegiatan pemenuhan kebutuhan pelayanan atas barang, jasa, dan atau/pelayanan adminsitrasi bagi warga negara yang diselenggarakan oleh penyelenggara pelayanan publik yang diatur peraturan perundangan-undangan berlaku (Ariany \& Putera, 2013). Dalam Undang-Undang Nomor 25 Tahun 2009 tentang Pelayanan Publik mendorong penyelenggara pelayanan publik secara berkesinambungan melakukan inovasi dan peningkatan kualitas layanan publik (Aristanto, 2019). Peraturan perundangan tersebut tentunya berlaku bagi unit dan satuan kerja di lingkungan Kementerian Pekerjaan Umum dan Perumahan Rakyat. Dalam dokumen Reformasi Birokrasi Kementerian Pekerjaan Umum dan Perumahan Rakyat 2020-2024 salah satu sasarannya adalah birokrasi yang memiliki pelayanan publik berkualitas dengan arah kebijakan: (1) Penguatan kelembagaan dan manajemen pelayanan; dan (2) Penguatan kapasitas pengelolaan kinerja pelayanan publik (Aristanto \& Damayanti, 2020). Dengan berdasar pada peraturan perundangan dan dokumen reformasi birokrasi Kementerian Pekerjaan Umum dan Perumahan Rakyat 2020-2024, maka berbagai kegiataan penataan organisasi dan penguatan kebijakan menjadi fokus program kerja Biro Komunikasi Publik, Sekretaris Jenderal Kementerian Pekerjaan Umum dan Perumahan Rakyat.

Upaya Kementerian Pekerjaan Umum dan Perumahan Rakyat mendorong peningkatan kinerja pelayanan publik ditindaklanjuti oleh Biro Komunikasi Publik dengan melakukan penilaian mandiri di berbagai unit pelaksana teknis di lingkungan Kementerian Pekerjaan Umum dan Perumahan Rakyat. Hasil penilaian mandiri tersebut menjadi dasar bagi Biro Komunikasi Publik melakukan intervensi melalui pelatihan dan pendampingan guna mendorong unit pelaksana teknis dapat melaksanakan pelayanan publik yang berkualitas (Aristanto \& Damayanti, 2021). Salah satu unit pelaksanan teknis yang menjadi sasaran intervensi melalui pelatihan dan pendampingan dengan mendasarkan penilaian mandiri adalah Balai Teknik Air Minum (BTAM). Dalam Peraturan Menteri Pekerjaan Umum dan Perumahan Rakyat Republik Indonesia Nomor : 20/PRT/M/2016 tentang Organisasi dan Tata Kerja Unit Pelaksana Teknis di Kementerian Pekerjaan Umum dan Perumahan Rakyat menjelaskan Balai Teknik Air Minum mempunyai tugas melaksanakan bimbingan teknis perencanaan dan pemberdayaan pengelolaan kelembagaan bidang air minum dengan wilayah kerja seluruh wilayah Indonesia.

Balai Teknik Air Minum yang mempunyai tugas dan fungsi yang sangat strategis tersebut sangat penting untuk dilakukan peningkatan pelayanan publik yang berkelanjutan, sehingga dapat memberikan tingkat kepuasan masyarakat pengguna pelayanan dari Balai Teknik Air Minum. Dalam penatakelolaan dokumen kebijakan dan standar pelayanan publik di lingkungan Balai Teknik Air Minum tentunya berdasarkan pada Peraturan Menteri Pendayagunaan Aparatur Negara (PAN RB) Nomor 15 Tahun 2014 tentang Pedoman Pelayanan Publik dan Peraturan Menteri Pendayagunaan Aparatur Negara dan Reformasi Birokrasi (PANRB) Nomor 17 Tahun 2017 tentang Pedoman Penilaian Kinerja Unit Penyelenggara Pelayanan Publik. Tuntutan kualitas pelayanan publik yang baik menjadi kewajiban yang harus dipenuhi oleh Balai Teknik Air Minum. Untuk menghadirkan pelayanan publik yang baik, maka pembenahan pada aspek tata kelola dan standar pelayanan publik bagi pelaksana pelayanan publik menjadi keharusan (Gedeona, 2011). Pada sisi yang lain, perbaikan tersebut merupakan bentuk ketaatan dalam pelaksanaan regulasi dan tugas pelayanan publik yang selalu diawasi dan di evaluasi oleh Kementerian Pendayagunaan Aparatur Negara dan Reformasi Birokrasi (PANRB) dan Ombudsman 
Republik Indonesia (ORI) mempunyai fungsi yang salah satunya adalah mengawasi penyelenggaraan Pelayanan Publik yang diselenggarakan oleh Pemerintah Pusat.

Kondisi existing pelayanan publik di Balai Teknik Air Minum berdasarkan penilaian mandiri masih terdapat beberapa hal yang perlu perbaikan, meliputi: (1) Masih terdapat dokumen pelayanan publik yang masih belum lengkap dan belum tersandarisasi; (2) Kegiatan survei kepuasan masyarakat belum memberikan informasi bagi masukan perbaikan pelayanan publik dan penilaian kinerja; (3) Layout desain ruangan yang kaku mengingat ruang pelayanan publik sekaligus berfungsi sebagai lobby; (4) Sarana informasi pelayanan publik yang belum tertata dalam kemudahan akses informasinya; (5) Belum memiliki sistem antrean (baik manual maupun elektronik); dan (6) Web Balai Teknik Air Minum yang masih belum informatif terhadap pelaksanaan pelayanan publik. Berdasarkan kondisi tersebut, kemudian menjadi dasar kebutuhan pelaksanaan pelatihan dan pendampingan penyusunan dokumen kebijakan dan standar pelayanan publik dilaksanakan di Balai Teknik Air Minum. Keberadaan dokumen kebijakan pelayanan publik dan standar pelayanan publik menjadi penting untuk dasar pijakan operasional bagi pelaksana pelayanan publik (Vinanda, 2017). Adapun tujuan pelatihan dan pendampingan penyusunan kebijakan dan standar pelayanan publik meliputi: (1) Melaksanakan penilaian mandiri untuk mengukur kinerja pelayakan publik saat ini; (2) Meningkatkan kemampuan dan pemahaman pelaksana pelayanan publik tentang kebijakan dan standar pelayanan publik; dan (3) Meningkatkan ketersediaan dan keterdukungan dokumen kebijakan dan standar pelayanan publik sesuai peraturan perundangan yang berlaku.

\section{METODE}

Pelaksanaan kegiatan pelatihan dan pendampingan penyusunan kebijakan dan standar pelayanan publik dilaksanakan di Balai Teknik Air Minum, dengan peserta kegiatan sebanyak 12 orang perwakilan dari unsur pimpinan dan staf pelaksana pelayanan publik. Pelaksanaan kegiatan ini secara efektif dilaksanakan selama 13 (tiga belas) hari kerja efektif bertempat di Balai Teknik Air Minum (BTAM) Bekasi. Metode yang digunakan dalam pelaksanaan kegiatan ini terdiri 4 (empat) meliputi: (1) Sosialisasi dan kunjungan lapangan sebagai kegiatan penyamaan persepsi antara unsur pimpinan dan staf pelaksana pelayanan publik dengan narasumber dan pendamping kegiatan; (2) Desk dokumen dilakukan untuk melakukan penilaian mandiri di tahap awal dan tahap air, sehingga dapat memberikan rekomendasi perbaikan pada dokumen kebijakan dan standar pelayanan publik; (3) Pelatihan dilakukan untuk meningkatkan kemampuan dan kapasitas pelaksana pelayanan publik; dan (4) Pendampingan. Adapun acauan yang digunakan dalam kegiatan ini mendasarkan pada Peraturan Menteri Pendayagunaan Aparatur Negara (PAN RB) Nomor 15 Tahun 2014 tentang Pedoman Pelayanan Publik dan Peraturan Menteri Pendayagunaan Aparatur Negara dan Reformasi Birokrasi (PANRB) Nomor 17 Tahun 2017 tentang Pedoman Penilaian Kinerja Unit Penyelenggara Pelayanan Publik (Ginarta et al., 2017). Adapun tahapan dan metode kegiatan pelatihan dan pendampingan penyusunan kebijakan dan standar pelayanan publik pada Balai Teknik Air Minum dijelaskan dalam Tabel 1. 
ABDIMAS: Jurnal Pengabdian Masyarakat Universitas Merdeka Malang

Volume 6, No. 2, May 2021: 153-165

Tabel 1. Tahapan, metode, dan hari efektif kegiatan

\begin{tabular}{lccc}
\hline \multicolumn{1}{c}{ Kegiatan } & \multicolumn{3}{c}{ Metode Kegiatan } \\
\cline { 2 - 4 }
\end{tabular}

\section{HASIL DAN PEMBAHASAN}

Kegiatan pelatihan dan pendampingan penyusunan kebijakan dan standar pelayanan publik dilaksanakan di Balai Teknik Air Minum (BTAM) Bekasi dengan difasilitasi oleh Biro Komunikasi Publik Sekretariat Jenderal Kementerian Umum dan Perumahan Rakyat. Merujuk pada tujuan yang diharapkan dapat dicapai dalam kegiatan ini, maka terdapat beberapa tahapan kegiatan yang dilaksanakan sebagai berikut.

\section{Kegiatan sosialisasi dan peninjauan lapangan}

Pelaksanaan kegiatan ini, dimulai dengan kegiatan sosialisasi dan peninjauan lapagan tahapan pendahuluan yang berlokasi di Balai Teknik Air Minum (BTAM) Bekasi. Sosialisasi dalam kegiatan ini bertujuan menyamakan persepsi antara Biro Komunikasi Publik Sekretariat Jenderal Kementerian Umum dan Perumahan Rakyat dengan pimpinan dan staf Balai Teknik Air Minum (BTAM) Bekasi tentang rencana pelaksanaan pelatihan dan pendampingan penyusunan kebijakan dan standar pelayanan publik. Pelaksanaan kegiatan sosialisasi kegiatan ini, dibuka oleh Dra. Yuni Erni Aguslin, M.Si (Kepala Balai Teknik Air Minum - BTAM) dan dilanjutkan dengan arahan dan paparan dari Ir. Lutfiel Anam Ahmad, MM (Staf Ahli Menteri PUPR Bidang Hubungan Antar Lembaga) yang diikuti oleh unsur pimpinan dan staf pelaksana pelayanan publik di lingkungan Balai Teknik Air Minum (BTAM). Hasil yang dicapai melalui sosialisasi pelaksanaan kegiatan ini adalah komitmen bersama unsur pimpinan dan staf pelaksana pelayanan publik, narasumber dan pendamping untuk meningkatkan berbagai aspek-aspek dalam peningkatan kinerja pelaksanaan pelayanan publik. 
Pelatihan dan Pendampingan Penyusunan Kebijakan dan Standar Pelayanan Publik pada Balai Teknik Air Minum Eko Aristanto, Indri Damayanti, Zaenal Aripin

Tabel 2. Pelaksanaan kegiatan sosialisasi dan peninjauan lapangan

\begin{tabular}{cll}
\hline Waktu & \multicolumn{1}{c}{ Kegiatan } & \multicolumn{1}{c}{ Narasumber } \\
\hline $09.00-09.30$ & $\begin{array}{l}\text { Pembukaan acara sosialisasi pelatihan dan pendampingan } \\
\text { penyusunan kebijakan dan standar pelayanan publik }\end{array}$ & $\begin{array}{l}\text { Yuni Erni Aguslin } \\
\text { (Kepala Balai Teknik Air Minum) }\end{array}$ \\
$\begin{array}{l}\text { Arahan dan paparan kebijakan dan standar pelayanan } \\
\text { publik di lingkungan kementerian pekerjaan umum dan } \\
\text { perumahan rakyat }\end{array}$ & $\begin{array}{l}\text { Lutfiel Anam Ahmad } \\
\text { (Staf Ahli Menteri PUPR bidang } \\
\text { Hubungan Antar Lembaga). }\end{array}$ \\
$\begin{array}{l}\text { Peninjauan lapangan sarana dan prasarana pelayanan } \\
\text { publik di lingkungan Balai Teknik Air Minum (BTAM) }\end{array}$ & \\
\hline
\end{tabular}

Setelah pelaksanaan kegiatan sosialisasi pelatihan dan pendampingan penyusunan kebijakan dan standar pelayanan publik, dilanjutkan dengan kegiatan site visit pada berbagai sarana dan prasarana pelayanan publik di lingkungan Balai Teknik Air Minum (BTAM) sesuai dengan instrumen pengukuran kinerja pelayanan publik yang merujuk pada Peraturan Menteri Pendayagunaan Aparatur Negara dan Reformasi Birokrasi (PANRB) Nomor 17 Tahun 2017 tentang Pedoman Penilaian Kinerja Unit Penyelenggara Pelayanan Publik. Adapun sarana dan prasarana pelayanan publik yang dilakukan peninjauan lapangan antara lain: (1) Sarana front office (front office untuk layanan konsultasi dan pengaduan); (2) Sarana penunjang (ruang laktasi, ruang fotocopy, kantin, arena bermain anak); (3) Sarana prasarana kebutuhan khusus (kursi roda, toilet difabel, ramp dan tangga difabel); dan (4) Parkir dan ruang tunggu.
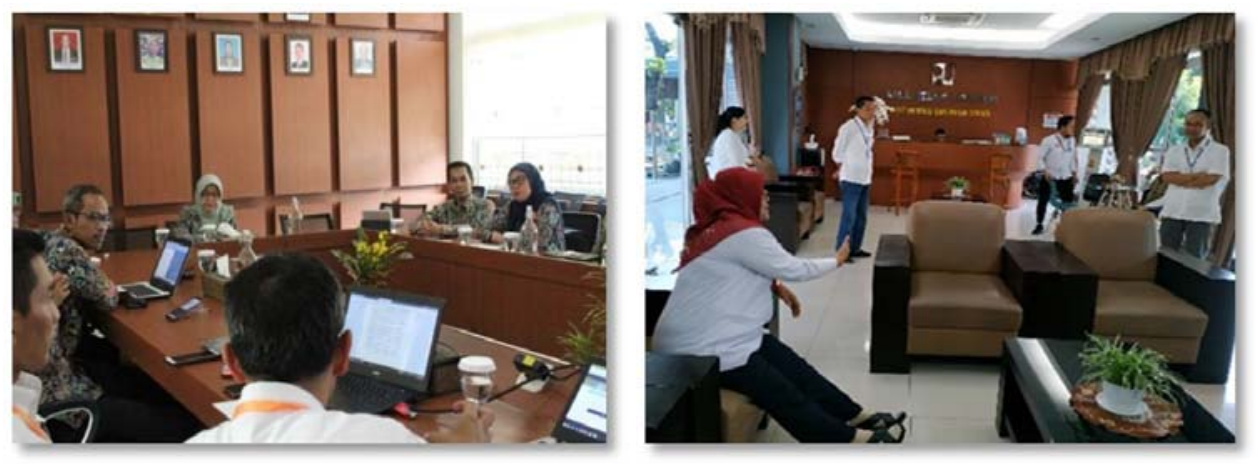

Gambar 1. Kegiatan sosialisasi dan peninjauan lapangan

\section{Review kebijakan dan standar pelayanan publik}

Kegiatan review kebijakan dan standar pelayanan publik dilakukan untuk melakukan berbagai telaah dokumen yang berkaitan dengan kebijakan dan standar pelayanan publik yang telah dilakukan di lingkungan Balai Teknik Air Minum (BTAM). Melalui review kebijakan dan standar pelayanan publik diharapkan dapat memetakan berbagai ketersediaan yang menjadi dasar pijakan bagi kebijakan dan standar pelayanan publik telah terkelola dan terdokumentasi dengan baik. Adapun berbagai dokumen yang dilakukan penelaahan meliputi: (1) Kebijakan standar pelayanan publik; (2) Maklumat pelayanan; 
ABDIMAS: Jurnal Pengabdian Masyarakat Universitas Merdeka Malang

Volume 6, No. 2, May 2021: 153-165

(3) Sistem antrian; (4) Dokumen survei kepuasan masyarakat; (5) Kode etik pelaksana layanan; (6) Sistem informasi elektronik; (7) Sistem informasi non elektronik; dan (8) Inovasi pelayanan publik. Kegiatan ini dilaksanakan bersama antara pengelola pelayanan publik Balai Teknik Air Minum (BTAM), Biro Komunikasi Publik Sekretariat Jenderal Kementerian Umum, dan Perumahan Rakyat dan pendamping kegiatan ini.

Tabel 3. Hasil review kebijakan dan standar pelayanan publik

\begin{tabular}{|c|c|c|c|}
\hline Review Dokumen & Hasil & & Keterangan \\
\hline \multicolumn{4}{|l|}{ Kebijakan Pelayanan } \\
\hline Standar pelayanan & Tersedia & $\begin{array}{l}\text { 1) } \\
\text { 2) }\end{array}$ & $\begin{array}{l}\text { Dukungan SK penetapan standar pelayanan (belum terstandar). } \\
\text { Masih memuat } 6 \text { komponen pelayanan ( } 14 \text { komponen yanlik) dan } \\
\text { belum diuraikan. } \\
\text { Terdapat SOP pada masing-masing pelayanan }\end{array}$ \\
\hline Maklumat pelayanan & Tersedia & 1) & Kalimat maklumat pelayanan yang belum terstandar \\
\hline Survei kepuasan masyarakat & Tersedia & 1) & $\begin{array}{l}\text { Indikator survei kepuasan masyarakat yang masih belum men- } \\
\text { gacu pada Permen PANRB No. } 14 \text { tahun } 2017 \text { tentang Pedoman } \\
\text { Penyusunan Survei Kepuasan Masyarakat ( } 9 \text { unsur SKM) } \\
\text { Tersedia laporan hasil survei kepuasan masyarakat }\end{array}$ \\
\hline Sistem antrian & Belum Tersedia & 1) & Belum tersedia secara manual dan digital \\
\hline Kode etik pelayanan publik & Belum Tersedia & 1) & Belum tersedia kode etik pelaksana pelayanan publik \\
\hline \multicolumn{4}{|l|}{$\begin{array}{l}\text { Sistem Informasi Pelayanan } \\
\text { Publik }\end{array}$} \\
\hline Sistem informasi elektronik & Tersedia & $\begin{array}{l}\text { 1) } \\
\text { 2) } \\
\text { 3) }\end{array}$ & $\begin{array}{l}\text { Tersedia web BTAM } \\
\text { Tersedia pelayanan daring Sipandu Satu } \\
\text { Web dimiliki Unor dan dikelola balai } \\
\text { Pemuktahiran data masih belum berkala. }\end{array}$ \\
\hline Sistem informasi non elektronik & Belum Tersedia & 1) & Belum tersedia papan informasi \\
\hline
\end{tabular}

Hasil review kebijakan dan standar pelayanan publik memberikan rekomendasi akan kebutuhan untuk melakukan peningkatan ketersediaan dan keterdukungan dokumen kebijakan dan standar pelayanan publik yang menjadi bagian yang tidak terpisahkan dalam penilaian kinerja pelayanan publik. Terhadap beberapa dokumen kebijakan dan standar pelayanan publik yang belum terstandar dan belum tersedia, maka akan menjadi bagian keluaran pelaksanaan kegiatan pelatihan dan pendampingan penyusunan kebijakan dan standar pelayanan publik di lingkungan Balai Teknik Air Minum (BTAM) Bekasi

\section{Pelatihan tata kelola kebijakan dan standar pelayanan publik}

Pelatihan tata kelola kebijakan dan standar pelayanan publik merupakan tahapan ke 3 di dalam rangkaian kegiatan ini. Dalam kegiatan pelatihan ini dimaksudkan dapat menyampaikan penerapan standar pelayanan publik sesuai peraturan yang berlaku agar dapat mendorong peningkatan kualitas pelayanan publik pada unit penyelenggara pelayanan publik di lingkungan Balai Teknik Air Minum (BTAM) Bekasi. Pelatihan ini bertujuan: (1) Menyampaikan penerapan standar pelayanan publik bagi unit penyelenggara pelayanan publik sesuai peraturan yang berlaku; (2) Menyampaikan implementasi standar 
pelayanan publik bagi unit penyelenggara pelayanan publik yang dapat mendorong peningkatan kualitas pelayanan publik pada unit penyelenggara pelayanan publik; dan (3) Best practice penerapan standar pelayanan publik yang dapat meningkatan hasil penilaian pelayanan publik bagi unit penyelenggara pelayanan publik. Adapun rangkaian kegiatan Pelatihan tata kelola kebijakan dan standar pelayanan publik dapat diihat pada Tabel 4.

Tabel 4. Pelatihan tata kelola kebijakan dan standar pelayanan publik

\begin{tabular}{|c|c|c|}
\hline Waktu & Kegiatan & Narasumber \\
\hline $09.00-09.30$ & $\begin{array}{l}\text { Pembukaan acara pelatihan tata kelola dan standar } \\
\text { pelayanan publik }\end{array}$ & $\begin{array}{l}\text { Lutfiel Annam } \\
\text { (Staf Ahli Menteri PUPR bidang } \\
\text { Hubungan Antar Lembaga). }\end{array}$ \\
\hline \multirow[t]{2}{*}{$09.30-11.00$} & $\begin{array}{l}\text { 1) Pemaparan kebijakan dan strategi bagaimana } \\
\text { peningkatan kualitas pelayanan publik }\end{array}$ & $\begin{array}{l}\text { Kedeputian Bidang Pelayanan Publik } \\
\text { (Kementerian Pendayagunaan Aparatur } \\
\text { Negara dan Reformasi Birokrasi - PANRB) }\end{array}$ \\
\hline & $\begin{array}{l}\text { 2) Paparan kepatuhan standar pelayanan publik dan } \\
\text { penanganan pengaduan berbasis propartif }\end{array}$ & $\begin{array}{l}\text { Adrianus Meliala } \\
\text { (Ombudsman Republik Indonesia) }\end{array}$ \\
\hline $11.00-12.00$ & Diskusi dan konsultasi tata kelola pelayanan publik & $\begin{array}{l}\text { Indri Damayanti } \\
\text { (Biro Komunikasi Publik, Sekjen } \\
\text { Kementerian Pekerjaan Umum dan } \\
\text { Perumahan Rakyat) }\end{array}$ \\
\hline $12.00-13.00$ & ISHOMA & \\
\hline $13.00-14.00$ & $\begin{array}{l}\text { Penjelasan teknis tentang tata kelola dan standar } \\
\text { pelayanan publik }\end{array}$ & $\begin{array}{l}\text { Eko Aristanto } \\
\text { (Universitas Merdeka Malang) }\end{array}$ \\
\hline
\end{tabular}
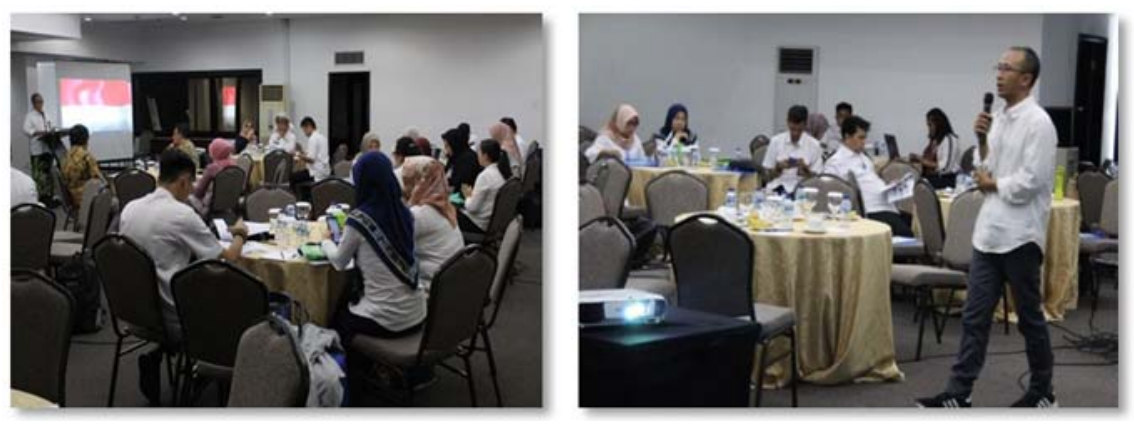

Gambar 2. Kegiatan pelatihan tata kelola kebijakan dan standar pelayanan publik

Pelaksanaan kegiatan pelatihan tata kelola kebijakan dan standar pelayanan publik di lingkungan Balai Teknik Air Minum telah terlaksana dan berjalan dengan lancar. Beberapa kesimpulan dalam kegiatan ini yang menjadi cacatan adalah: (1) Meningkatkan pemahaman tentang regulasi, tata kelola dan standar pelayanan pelayanan publik; (2) Meningkatkan kesadaran tentang pentingnya peningkatan kualitas pelayanan publik bagi masyarakat dan pengguna layanan Balai Teknik Air Minum; dan (3) Peningkatan pengetahuan tentang berbagai aspek -aspek penilaian kinerja pelayaan publik yang akan dilaksanakan Balai Teknik Air Minum. Peningkatan pemahaman tentang tata kelola dan standar pelayanan publik yang baik menjadi dasar bagi pelaksana pelayanan publik untuk menyusun berbagai dokumen kebijakan dan kelengakapan penatalaksaaan pelayanan publik di lingkungan Balai Teknik Air Minum. 
ABDIMAS: Jurnal Pengabdian Masyarakat Universitas Merdeka Malang

Volume 6, No. 2, May 2021: 153-165

\section{Pendampingan penyiapan dokumen tata kelola kebijakan dan standar pelayanan publik}

Pelaksanaan kegiatan pendampingan penyiapan dokumen tata kelola kebijakan dan standar pelayanan publik merupakan tahap lanjutan sebagai implementasi dari pelaksanaan kegiatan pelatihan. Hal ini dilakukan dengan memperhatikan review kebijakan dan standar pelayanan publik dan respon positif pelaksanaan pelatihan tata kelola kebijakan dan standar pelayanan publik yang telah dilaksanakan pada tahap sebelumnya. Dalam pendampingan ini dilakukan penyusunan dokumen kebijakan dan standar pelayanan publik yang harus terpenuhi sebagai landasan pelaksanaan pelayaan publik dan sekaligus pedoman bagi pelaksnaan pelayanan publik di lingkungan Balai Teknik Air Minum. Sebagai rujukan dalam penyusunan dokumen kebijakan dan standar pelayanan publik tersebut mengacu pada Peraturan Menteri PANRB Nomor 15 Tahun 2014 tentang Pedoman Pelayanan Publik dan Peraturan Menteri PANRB Nomor17 Tahun 2017 tentang Pedoman Penilaian Kinerja Unit Penyelenggara Pelayanan Publik.
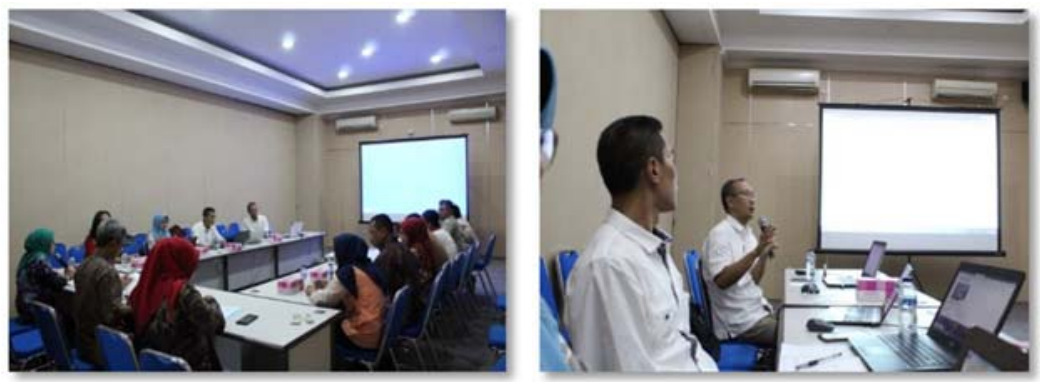

Gambar 3. Diskusi pendampingan penyiapan dokumen tata kelola kebijakan dan standar pelayanan publik

Dalam pendampingan ini dilakukan penyusunan berbagai dokumen kebijakan dan standar pelayanan publik yang belum tersedia. Dokumen tersebut terutama pada aspek standar pelayanan dan aspek sistem informasi pelayanan publik yang menjadi indikator kinerja pelayanan publik yang telah ditetapkan dalam Peraturan Menteri PANRB Nomor 17 Tahun 2017 tentang Pedoman Penilaian Kinerja Unit Penyelenggara Pelayanan Publik.

Tabel 5. Dokumen hasil pendampingan penyiapan dokumen tata kelola kebijakan dan standar pelayanan publik

\begin{tabular}{|c|c|c|}
\hline Aspek & & Dokumen Hasil Pendampingan \\
\hline \multirow[t]{5}{*}{ Aspek Standar Pelayanan } & 1) & $\begin{array}{l}\text { Surat keputusan penetapan standar pelayanan publik Balai Teknik Air } \\
\text { Minum }\end{array}$ \\
\hline & 2) & Maklumat pelayanan publik Balai Teknik Air Minum \\
\hline & 3) & $\begin{array}{l}\text { Pedoman pelaksanaan dan pelaporan Survei Kepuasan Masyarakat (SKM) } \\
\text { Balai Teknik Air Minum }\end{array}$ \\
\hline & 4) & SOP sistem atrian Balai Teknik Air Minum \\
\hline & 5) & $\begin{array}{l}\text { Kode etik pelaksana penyelenggara pelayanan publik Balai Teknik Air } \\
\text { Minum }\end{array}$ \\
\hline \multirow[t]{3}{*}{ Aspek Sistem Informasi Pelayanan Publik } & 1) & $\begin{array}{l}\text { Penambahan informasi pelayaan publik pada website Balai Teknik Air } \\
\text { Minum }\end{array}$ \\
\hline & 2) & Leafleat pelayanan publik Balai Teknik Air Minum \\
\hline & 3) & Desain dan layout ruang pelayanan publik Balai Teknik Air Minum. \\
\hline
\end{tabular}



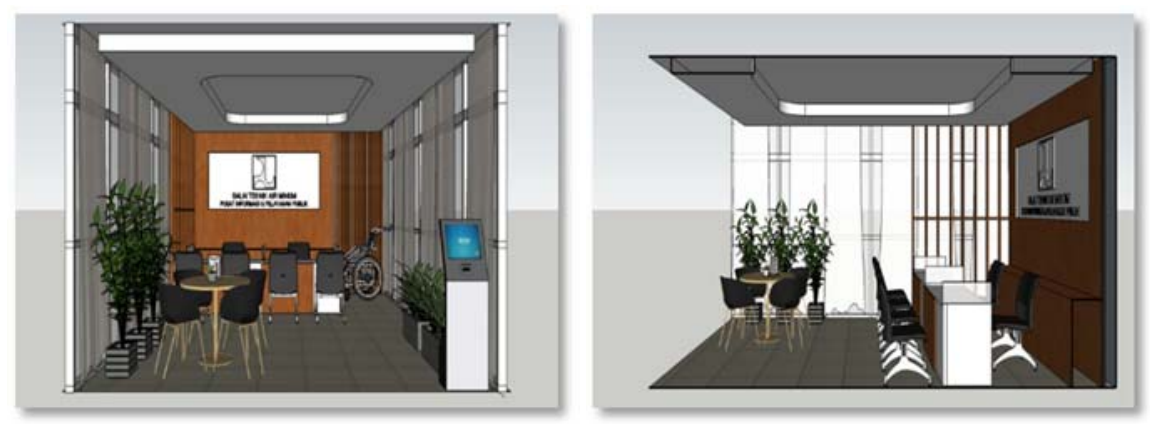

Gambar 4. Penataan layout ruang utama pelayanan publik di Balai Teknik Air Minum

Dalam pendampingan penyiapan dokumen tata kelola kebijakan dan standar pelayanan publik tidak hanya tertuju ada sisi administrasi dan dokumen pelayanan publik saja. Namun, dalam pendampingan ini juga memberikan beberapa rekomendasi untuk perbaikan pelayanan publik ke depan baik yang bersifat jangka pendek dan jangka panjang. Hal-hal yang direkomendasikan diharapkan dapat segera ditindakanjuti lebih lanjut oleh Balai Teknik Air Minum.

Tabel 6. Dokumen hasil pendampingan penyiapan dokumen tata kelola kebijakan dan standar pelayanan publik

\begin{tabular}{|c|c|c|}
\hline Aspek & & Rekomendasi Hasil Pendampingan \\
\hline \multirow[t]{5}{*}{ Aspek Profesionalisme SDM } & 1) & $\begin{array}{l}\text { Perlunya pelatihan budaya pelayanan prima bagi pelaksana pelayanan pub- } \\
\text { lik. }\end{array}$ \\
\hline & 2) & $\begin{array}{l}\text { Adanya atribut pembeda antara pelaksanan pelayanan publik dengan pe- } \\
\text { gawai lainnya (dalam bentuk PIN atau Rompi) }\end{array}$ \\
\hline & 3) & Sistem pergantian petugas pada saat jam istirahat pada jam pelayanan. \\
\hline & 4) & $\begin{array}{l}\text { Pembuatan alur pelayanan publik pada setiap jenis layanan publik yang dise- } \\
\text { diakan. }\end{array}$ \\
\hline & 5) & $\begin{array}{l}\text { Penyiapan buku tamu digital memudahkan sistem antrian, eksekusi layanan } \\
\text { dan feedback survei kepuasan masyarakat (SKM). }\end{array}$ \\
\hline \multirow[t]{4}{*}{ Aspek Sarana Prasarana } & 1) & Penyediaan kursi roda di sudut ruang Layanan Publik. \\
\hline & 2) & Kamar mandi dan toilet yang ramah difabel. \\
\hline & 3) & Penyediaan ruang laktasi dan ruang bermain anak. \\
\hline & 4) & Penataan layout ruang utama pelayanan publik di Balai Teknik Air Minum \\
\hline
\end{tabular}

\section{Evaluasi akhir pelaksanaan pelatihan dan pendampingan}

Tahapan akhir yang dilaksanakan dalam pelatihan tata kelola kebijakan dan standar pelayanan publik adalah melakukan kegiatan evaluasi akhir kegiatan. Kegiatan evaluasi akhir melakukan evaluasi secara komprehensif atas hasil kegiatan review kebijakan dan standar pelayanan publik, pelatihan dan pendampingan penyiapan dokumen tata kelola kebijakan dan standar pelayanan publik. Evaluasi pertama pada 6 (enam) aspek yang ditetapkan dalam Peraturan Menteri PANRB Nomor 17 Tahun 2017 tentang Pedoman Penilaian Kinerja Unit Penyelenggara Pelayanan Publik yang meliputi: (1) Kebijakan pelayanan; (2) Profesionalisme SDM; (3) Sarana prasaran peayanan publik; (4) Sistem informasi pelayanan publik; (5) Konsultasi dan pengaduan; dan (6) Inovasi pelayanan publik mencapai skor nilai 2,66 $(53,30)$ kategori $C$ (Cukup). Melalui kegiatan pendampingan, maka berbagai kebutuhan dokumen kebijakan dan standar pelayanan telah tersusun dan terdokumentasi dengan baik sesuai Peraturan Menteri PANRB Nomor 17 
ABDIMAS: Jurnal Pengabdian Masyarakat Universitas Merdeka Malang Volume 6, No. 2, May 2021: 153-165

Tahun 2017 tentang Pedoman Penilaian Kinerja Unit Penyelenggara Pelayanan Publik. Hasil penilaian mandiri Biro Komunikasi Publik, Sekretariat Jenderal Kementerian Pekerjaan Umum dan Perumahan Rakyat terhadap kinerja pelayanan publik Balai Teknik Air Minum setelah kegiatan pendampingan mencapai skor nilai 3,45 $(69,129)$ kategori B- (Baik dengan Catatan). Nilai kinerja pelayanan publik dapat meningkat kembali manakala beberapa rekomendasi yang diusulkan segera dapat direalisasi meliputi: (1) Penyediaan kursi roda; (2) Penerapan sistem antrian; (3) Penyediaan ruang bermain anak dan ruang laktasi; (4) Papan pengumuman informasi layanan publik; dan (5) Inovasi pelayanan publik berbasis web atau Android yang memudahkan proses pelayanan yang bersifat administrasi.
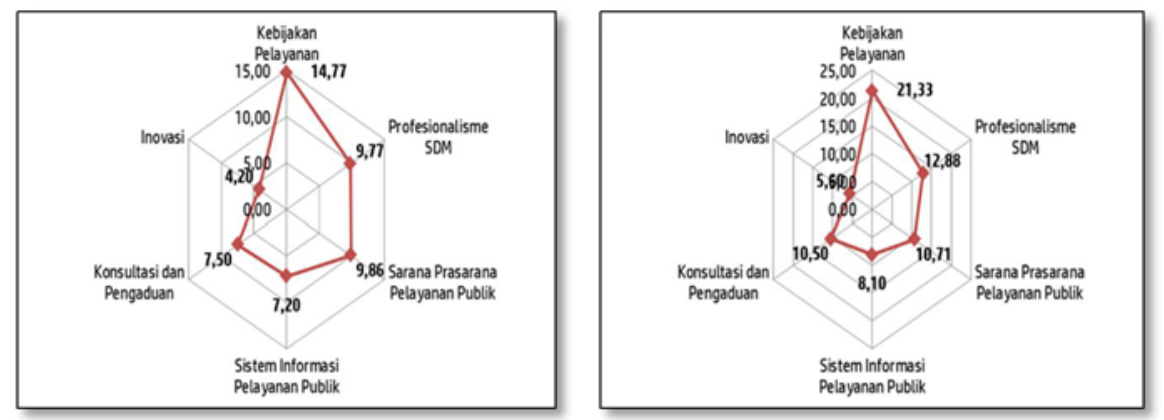

Gambar 5. Hasil penilaian mandiri sebelum pendampingan skor 2,66 $(53,30)$ kategori C (Cukup)

Gambar 6. Hasil penilaian mandiri sebelum pendampingan skor 3,45 $(69,129)$ kategori B- (Baik dengan catatan)

Berbagai rangkaian kegiatan pelatihan dan pendampingan penyiapan dokumen tata kelola kebijakan dan standar pelayanan publik telah dilasanakan dengan baik sesuai dengan tujuan yang dicapai. Terhadap pelaksanaan pelatihan tersebut dilakukan evaluai kegiatan yang bersandar pada 5 (lima) indikator evaluasi meliputi: (1) Dukungan unsur pimpinan dalam kegiatan; (2) Peningkatan pemahaman kebijakan dan standar pelayanan publik; (3) Partisipasi dan keterlibatan pelaksana dalam proses pendampingan; (4) Pencapaian penyelesaian penyusunan kebijakan dan standar pelayanan; dan (5) Efektivitas pelatihan dan pendampingan.

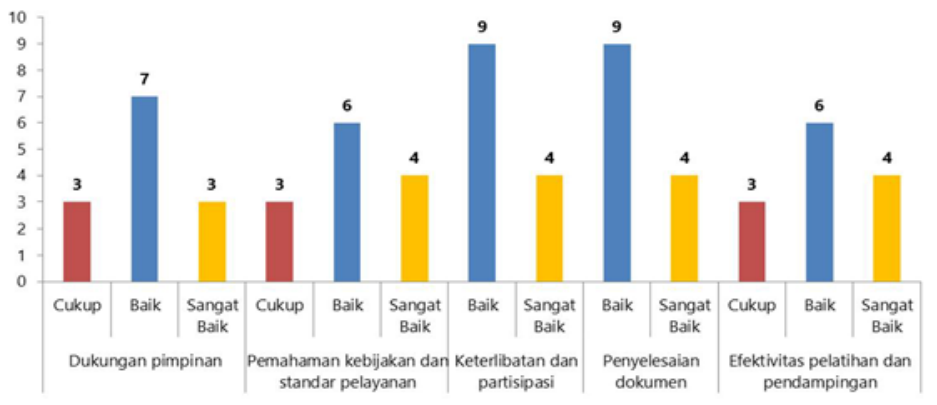

Gambar 7. Hasil evaluasi kegiatan pelatihan dan pendampingan 
Hasil evaluasi kegiatan pelatihan dan pendampingan penyiapan dokumen tata kelola kebijakan dan standar pelayanan publik sebagai berikut: (1) Indikator dukungan unsur pimpinan dalam kegiatan dengan skor sebesar 52 kategori baik); (2) Indikator peningkatan pemahaman kebijakan dan standar pelayanan publik dengan skor sebesar 53 kategori sangat baik; (3) Indikator partisipasi dan keterlibatan pelaksana dalam proses pendampingan dengan skor sebesar 56 kategori sangat baik; (4) Indikator pencapaian penyelesaian penyusunan kebijakan dan standar pelayanan dengan skor sebesar 56 kategori sangat baik; dan (5) Indikator efektivitas pelatihan dan pendampingan dengan skor sebesar 53 (sangat baik). Secara kumulatif untuk 5 (lima) indikator evaluasi menjelaskan bahwa pelaksanaan pelatihan dan pendampingan dengan rerata sebesar 54 kategori sangat baik.

\section{Pembahasan}

Pelaksanaan pelatihan dan pendampingan penyusunan dokumen kebijakan dan standar pelayanan publik pada Balai Teknik Air Minum (BTAM) Bekasi pada akhirnya memberikan pemahaman yang komprehensif pada petugas pelayanan publik dapat secara mandiri memetakan berbagai kelemahan pada sisi administrasi dalam upaya membangun kebijakan dan standar pelayanan publik yang baik sesuai peraturan yang berlaku. Disamping itu, kegiatan ini memberikan nilai lebih dalam meningkatkan ketersediaan dan keterdukungan dokumen kebijakan dan standar pelayanan publik untuk melengkapi dokumen-dokumen yang telah ada. Kegiatan ini juga menjadi salah satu pendukung dalam memenuhi komponen pengungkit pada Penguatan Kualitas Pelayanan Publik dengan bobot $10 \%$ dari rencana usulan Pembangunan Zona Integritas menuju Wilayah Bebas Korupsi (WBK) dan Wilayah Birokrasi Bersih dan Melayani (WBBM) yang sedang dilaksanakan di lingkungan Kementerian Pekerjaan Umum dan Perumahan Rakyat. Dimana Zona Integritas menurut Peraturan Menteri Pendayagunaan Aparatur Negara dan Reformasi Birokrasi Nomor 52 Tahun 2014 merupakan predikat yang diberikan kepada instansi pelayanan publik pemerintah yang berkomitmen dan mengimplemantasikannya untuk dapat mewujudkan WBK/WBBM dengan melakukan reformasi birokrasi di lingkungannya (Hanafi \& Harsono, 2020; Hapsari et al., 2019). Melalui kegiatan ini juga meningkatkan ketersediaan dan kualitas dokumen standar pelayanan publik untuk mendorong upaya peningkatan pelayanan publik secara berkelanjutan di lingkungan Balai Teknik Air Minum (BTAM) Bekasi. Melalui pelaksanaan kegiatan ini juga memberikan masukan upaya inovasi pelayanan publik dengan melakukan perancangan apblikasi sistem antrian berbasis Android dengan penetapan nomor urut antrian dan jam kedatangan ke lokasi pelayanan. Disamping itu, inovasi pelayanan publik lainya yang dapat kembangkan pada kegiatan Survei Indeks Kepuasan Masyarakat (IKM) dengan sistem digital untuk lebih memudahkan pengguna layanan dengan cepat dan cermat dengan tetap memperhatikan indikator Survei Indeks Kepuasan Masyarakat yang merujuk pada Peraturan Menteri Pendayagunaan Aparatur Negara dan Reformasi Birokrasi Nomor 14 Tahun 2017.

\section{SIMPULAN DAN SARAN}

Pelaksanaan pelatihan dan pendampingan penyusunan dokumen kebijakan dan standar pelayanan publik pada Balai Teknik Air Minum (BTAM) Bekasi telah terlaksana dengan lancar. Kegiatan 
ABDIMAS: Jurnal Pengabdian Masyarakat Universitas Merdeka Malang

Volume 6, No. 2, May 2021: 153-165

yang telah dicapai dalam kegiatan tersebut meliputi: (1) Teridentifikasi berbagai kelemahan dalam peningkatan kinerja pelayanan publik yang telah dilaksanakan; (2) Peningkatan pemahaman pimpinan dan pelaksana pelayanan publik tentang penatakelolaan dokumen kebijakan dan standar pelayanan publik; (3) Tersusunnya dokumen kebijakan dan standar pelayanan publik (surat keputusan penetapan standar pelayanan publik, maklumat pelayanan, survei kepuasan masyarakat, sistem antrian, kode etik pelaksana pelayanan publik, serta rekomendasi perbaikan sarana prasarana fasilitas pelayanan publik) yang merujuk pada Peraturan Menteri PANRB No 15 Tahun 2014 dan Peraturan Menteri PANRB No. 17 Tahun 2017; (4) Hasil penilaian mandiri menunjukan peningkatan kinerja pelayanan publik dari 2,66 $(53,30)$ kategori C (Cukup) menjadi 3,45 $(69,13)$ kategori B- (Baik dengan Catatan); dan (5) Hasil evaluasi kegiatan pelatihan dan pendampingan penyiapan dokumen tata kelola kebijakan dan standar pelayanan publik pada 5 (lima) indikator dengan skor sebesar 54 dengan kategori sangat baik.

Dalam pelaksanaan kegiatan ini dengan memperhatikan durasi kegiatan, maka pelaksanan lebih menekankan aspek administrasi dalam bentuk penyusunan dokumen kebijakan dan standar pelayanan publik yang menjadi kebutuhan penilaian kinerja pelayanan publik, sehingga masih belum secara optimal meningkatkan softskill petugas pelayanan publik dalam pelayanan publik. Berbagai dokumen kebijakan dan standar pelayanan publik yang telah disusun, segera dilakukan pemberian legalitas dokumen dan didokumentasi dalam bentuk dokumen fisik (untuk kebutuhan penilaian kinerja oleh Kementerian PANRB dan Ombudsman Republik Indonesia (ORI) dan soft file untuk kebutuhan upload penilaian kinerja pelayanan publik. Untuk saran yang bersifat pengadaan tambahan fasilitas sarana bagi difabel, ruang laktasi dan ruang bermain anak untuk dapat segera direalisasikan. Sedangkan saran yang bersifat perubahan fasad dan layout ruang utama pelayanan publik segera dapat dimasukan penganggaran kegiatan pelayanan publik tahun selanjutnya. Bagi para pelaksanan kegiatan pelatihan pelayanan publik yang akan datang, harapannya perlu memberikan pelatihan pelayanan prima yang bersertifikasi untuk petugas pelayanan publik untuk kepentingan peningkatan kualitas petugas dan dokumen pendukung kompetensi petugas pelayanan publik.

\section{UCAPAN TERIMA KASIH}

Kami mengucapkan terima kasih kepada Kepala Balai Teknik Air Minum (BTAM) Bekasi yang telah memberikan kesempatan berbagi pengetahuan pelayanan publik, Staf Ahli Menteri PUPR Bidang Hubungan Antar Lembaga yang selalu mendorong pentingnya pelayanan publik di lingkungan Kementerian Pekerjaan Umum dan Perumahan Rakyat dan Kepala Biro Komunikasi Publik, Sekretariat Jenderal Kementerian Pekerjaan Umum dan Perumahan Rakyat yang telah menfasilitasi dan mendanai pelaksanaan kegiatan ini. Semoga pelaksanaan pelatihan dan pendampingan ini dapat meningkatkan ketersediaan dan keterdukungan dokumen kebijakan dan standar pelayanan publik yang menjadi dasar penilaian pelayanan publik di lingkungan Balai Teknik Air Minum. 


\section{DAFTAR PUSTAKA}

Aini, N. (2019). Evaluasi kinerja pegawai untuk mewujudkan pelayanan publik dalam perspektif good governance. JISoP: Jurnal Inovasi Ilmu Sosial dan Politik, 1(1), 43-57. http://dx.doi.org/10.33474/jisop.v1i1.2671

Ariany, R., \& Putera, R. E. (2013). Analisis kinerja organisasi pemerintah dalam memberikan pelayanan pulik di Kota Pariaman. Mimbar: Jurnal Sosial dan Pembangunan, 29(1), 33-40. https://doi.org/10.29313/mimbar.v29i1.364

Aristanto, E. (2019). Panduan Penilaian Kinerja Unit Penyelenggara Pelayanan Publik. Fakultas Ekonomi dan Bisnis, Universitas Merdeka Malang.

Aristanto, E., \& Damayanti, I. (2020). Panduan Pelaksanaan Survei Indeks Kepuasan Masyarakat (IKM) bagi Unit Penyelenggara Pelayanan Publik Lingkungan Sekretariat Jenderal Kementerian Pekerjaan Umum dan Perumahan Rakyat. Fakultas Ekonomi dan Bisnis, Universitas Merdeka Malang.

Aristanto, E., \& Damayanti, I. (2021). Peningkatan kapasitas dan pendampingan penilaian mandiri kinerja pelayanan publik. Jurnal Inovasi Hasil Pengabdian Masyarakat (JIPEMAS), 4(1), 57-68. https://doi.org/10.33474/jipemas.v4i1.7787

Ginarta, K., Tukiyat, I., \& Jamili, M. (2017). Kinerja pegawai dalam pelayanan publik pada Dinas Pendapatan Daerah Kabupaten Barito Timur. Administraus: Jurnal Ilmu Administrasi dan Manajemen, 1(1), 26-39.

Hanafi, A. S., \& Harsono, M. (2020). Pelaksanaan reformasi birokrasi dengan pembangunan zona integritas pada Kementerian Perindustrian. Jurnal Informasi dan Komunikasi Administrasi Perkantoran, 4(1), 32-37.

Hapsari, J., Purnaweni, H., \& Priyadi, B. P. (2019). Implementasi pembangunan zona integritas menuju wilayah bebas dari korupsi dan wilayah birokrasi bersih dan melayani di BBWS Pemali Juana Semarang. Dialogue: Jurnal Ilmu Administrasi Publik, 1(1), 25-42.

https://doi.org/10.14710/dialogue.v1i1.5222

Gedeona, H. T. (2011). Strategi penyusunan standar pelayanan publik dengan pendekatan partisipasi masyarakat dan stakeholders. Jurnal Ilmu Administrasi, 8(3), 300-311. https://doi.org/10.31113/jia.v8i3.292

Tunggul, A. M., Isnanto, R., \& Nurhayati, O. D. (2016). Evaluasi kinerja organisasi publik dengan mengunakan pendekatan Balanced Scorecard dan Analytic Network Process. Jurnal Sistem Informasi Bisnis, 6(2), 124-132. https://doi.org/10.21456/vol6iss2pp124-132

Vinanda, M. F. (2017). Studi tentang pelaksanaan kepatuhan dalam standar pelayanan publik di Kantor Kelurahan Bantuas Kota Samarinda. EJournal Pemerintahan Integratif, 5(4), 507-518. 